\title{
Pro-Environmental and Health-Promoting Grounds for Restitution of Flax (Linum usitatissimum L.) Cultivation
}

\author{
Aleksander Kiryluk ${ }^{1 *}$, Joanna Kostecka² \\ 1 Department of Technology in Environmental Engineering, Faculty of Civil Engineering and Environmental \\ Sciences, Bialystok University of Technology, ul. Wiejska 45E, 15-351 Białystok, Poland \\ 2 Department of the Basis of Agriculture and Waste Management, Environmental Protection and Management, \\ Institute of Agricultural Sciences, College of Natural Sciences, University of Rzeszow, Poland \\ * Corresponding author's e-mail: a.kiryluk@pb.edu.pl
}

\begin{abstract}
The current state of the world's ecosystems requires many measures to restore opportunities, if not for their reconstruction, then to stop the rate of biodiversity loss. One of the areas where this should happen is industrial agriculture. In order to diversify the large-scale monoculture crops dominated by cereals and fodder crops, science and practice draw attention to the need to introduce the plants of smaller or marginal significance into cultivation. Flax (Linum usitatissimum L.) is a species with special properties and great utility from the ancient times to the present. Currently, Canada is the largest producer of flax in the world, while France, Belgium and the Netherlands in Europe. The aim of the work was to assess the state of its cultivation (area and volume of production) and determine the possibilities of restituting this species in Poland. The analysis of the available materials indicates that the largest areas of flax cultivation occurred in the nineteenth and twentieth centuries, when flax competed with cotton as a raw material for the production of textile products. In the interwar period, Poland had a well-developed linen industry for flax processing. Large quantities of high-quality linseed oil were also produced. In the 1990s, the production of flax amounted to several hundred hectares, and after Poland's accession to the EU, the area of cultivation and production of oil flax increased. Bearing in mind the pro-environmental qualities of linen and linseed oil, there is a need to popularize this species and increase the cultivation area, for which the climatic and soil conditions in moderate climate are very favorable.
\end{abstract}

Keywords: biodiversity, fibrous flax, oil flax, restitution of cultivation, useful properties

\section{INTRODUCTION}

Nowadays, when everyone is wondering how to overcome the emerging recession, the accompanying ecological crisis and numerous social problems, there is an opportunity to abandon the models of unlimited economic growth that have been used for a long time and find effective actions implementing the strategy of sustainable development. It is the time for innovative reconstruction plans, which should also include a change of mindset and be based on greater respect for the biosphere (Wilson, 2016; Kostecka and Butt, 2019). It seems that we have the last opportunity to reconcile the interests of people and the planet, taking care of development, prosperity and equality in society, while engaging in the protection of the natural ecosystems and resources of the Earth. Global and local economies can also prosper when based on new paradigms with social foundations, under the so-called "planetary boundaries" (Rockström et al., 2009; Biermann, 2012; Nordhaus et al., 2012). The world, Europe and Poland need a holistic, modern concept of transformation, taking into account the social and ecological challenges of the 21 st century as a starting point for a long-term policy and a vision of development in cooperation with science (Hardt, 2017; Kostecka, 2013, 2019).

The current state of the degraded ecosystems of the world (Millenium..., 2005) requires many decisive actions to rebuild them and stop the 
rate of biodiversity loss (Wilson, 2016). One of the areas where this should happen is industrial agriculture.

In order to diversify the large-scale monoculture crops dominated by cereals and fodder crops, science and practice draws attention to the need to introduce the plants of smaller or even marginal significance, into cultivation. One of them may be common flax (Linum usitatissimum L.), which has many beneficial utility features (Lewandowski, 2008). This species is characterized by high adaptability to various climatic conditions, which means that it is cultivated from the Mediterranean and North Africa through the Middle East, the Caucasus to India. It is also grown in Canada. In Europe, the leading countries include France, Belgium and the Netherlands (Figure 1, Table 1).

Seventy percent of the world's crop is produced in Europe, 10000 companies from $14 \mathrm{EU}$ countries cover all stages of the fiber's production and transformation. They associate in the European Confederation of Linen and Hemp (CELC). They have ambitions to build a new quality: Zero Irrigation, Zero GMO, Zero waste (Hunter, 2012).

Flax prefers light, well-drained, not very fertile soils. This plant is grown to obtain fiber and oil. Flax seeds (Semen lini) are used in the pharmaceutical and food industry. They contain 35\% oil, $20 \%$ protein, enzymes and glycosides of oleic, linoleic and stearic acids (Popis et al., 2015). In the past, flax was widely used in folk medicine because of its many medicinal properties (Musial, 2017). In the everyday life of the Podlasie village in the nineteenth and twentieth centuries, it was an important and profitable crop. It also played a cultural role in the rural environment (Gawel, 2009; Łuczaj, 2011). In 1928, the production of the flax fiber in Poland amounted to 60 thousand tons and was slightly lesser than cotton imports. Due to the state protection, the linen industry remained despite the economic crisis in the interwar period. The reduction in the cultivation area and the liquidation of the linen industry took place in the 1990s. The attempts at revitalizing the linen industry are currently underway. The linen fabrics and clothing are now considered exclusive products, constituting a niche in the globalized clothing market. Creating a fashion for ecological clothing (Hołubowicz-Kliza, 2015) gives a chance for revitalization of flax cultivation in Europe. The basis for these activities should be the introduction of cultivation of this plant on lighter soils, often fallow lands, the acreage of which, e.g. in Poland, is increasing. The effectiveness of revitalization will also depend on the increase in profitability of crops. In the era of synthetic plastics and increasing the area of cotton, the demand for flax is lesser than before, but in some countries it is already gradually increasing. Popularization and introduction of flax (including its beneficial functionalities) to cultivation is currently important in the globalization of the agricultural production and reducing the diversity of crop species (Buchwald et al., 2017; Kaeufler, 1999). Currently, most research and publications refer to the cultivation for the needs of oil, while there are few studies on the cultivation of flax for fiber (Preisner et. al, 2015). The presented article attempts to popularize the knowledge about all the usability of flax.

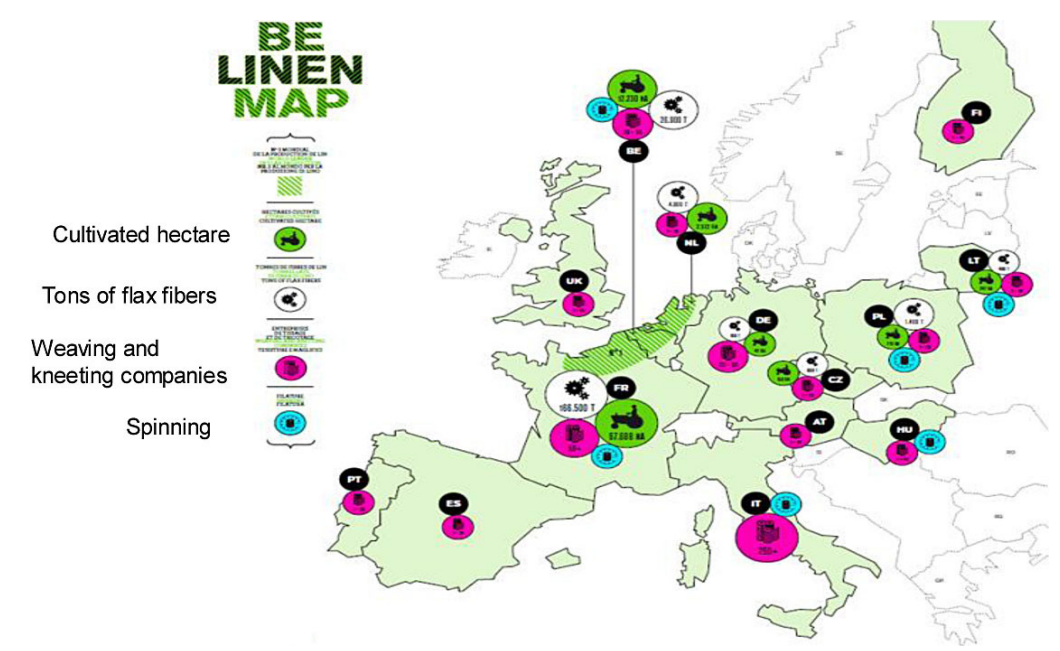

Figure 1. European flax industry [after Hunter 2012, changed, https //www.knittingindustry.com/european-flax-new-label-guarantees-quality/] 
Table 1. The flax production in Europe [Hunter 2012]

\begin{tabular}{|c|c|c|}
\hline Country & Cultivated hectare & $\begin{array}{c}\text { Tons of flax fibers } \\
\text { [tons] }\end{array}$ \\
\hline France & 67.688 & 166.500 \\
\hline Belgium & 12.230 & 26.900 \\
\hline Netherlands & 2.572 & 4.800 \\
\hline Poland & 779 & 1400 \\
\hline Lithuania & 247 & 400 \\
\hline Czech Republic & 156 & 600 \\
\hline Denmark & 42 & 100 \\
\hline
\end{tabular}

\section{MATERIAL AND METHODS}

The work is of review and discussion nature. In order to implement the topic, the available literature on biology, useful properties, history of cultivation and technology of flax processing were selected. The collected materials were subjected to selection and evaluation. The data available on the websites of the Central Statistical Office, the Institute of Natural Fibers and Herb Plants, the Polish Chamber of Flax and Hemp, the Agricultural Advisory Center, as well as own materials from field work in agricultural areas in the Podlasie Voivodship, were applied in this paper. The environmental benefits resulting from increasing the area of this crop were also discussed.

\section{HISTORY OF CULTIVATION AND USE OF FLAX}

Flax has been grown since the ancient times. Historical sources say that flax already appeared in the pre-ceramic Neolithic, i.e. around 8500 BC. (Nowiński, 1970). The fabrics made of flax were found in the Babylonian tombs dating from around $3000 \mathrm{BC}$. In the Bible, linen is mentioned many times; for the first time in Exodus (9: 23-25, 31), where there is the verse: "Flax and barley were destroyed, because barley already had ears of corn and flax flowers." The processing of linen in biblical times was done by women, as evidenced by the verse from the Book of Proverbs (31, 10-31): "She cares for flax and wool ... makes coats, ... makes and sells canvas" (Biblia Tysiąclecia, 2003). The manuscripts from Qumran were wrapped in linen canvases, dating back to around $70 \mathrm{CE}$. In the modern era, flax was widespread in the Mediterranean Basin owing to the Phoenician merchants. Then, its cultivation in Europe began. Its seeds were found in the excavations in Biskupin (Lityńska-Zając and
Wasylikowa, 2005). In 1794, a mechanical ginner for flax was used, which facilitated the extraction of linseed oil and increased the area of its cultivation. The medicinal uses of various plant species, including Linum usitatissimum, have already accompanied ancient civilizations. This was facilitated by the ability to transfer knowledge through a letter that was used to transfer information in space and time. For a long time, linen fabrics were the most popular raw material for clothes and bedding in Poland, mainly because the entire process of obtaining the raw material, from sowing seeds to the finished canvas, could be carried out by each villager. Michał Fedorowski noted in 1883: "The Lithuanian peasant has not bought factory products yet. It wears the homespun coat, underwear also made of linen made at home."

At the same time, the production of cotton fabrics increased, which in the nineteenth century dominated the global markets, including the textile industry in Poland. In 1810, Frenchman Filip de Girard constructed a mechanical spinner for flax fiber, which allowed for greater processing of flax fiber and its competition with cotton. In 1831, the first mechanical flax spinning mill in Poland was opened near Warsaw based on new machines for processing flax fiber. The name of the city of Żyrardów comes from the name Girard, where the country's largest linen factory was established in the mid-nineteenth century. The production of domestic flax increased; in 1928 it amounted to 60,000 tons and equaled the volume of imported cotton. The Polish state secured the development of the linen industry, including by crediting the expansion of the factories of the linen industry, raising tariffs on imported fibers, which halted the effects of the great economic crisis and did not affect this branch of production. The linen industry was clearly collapsed only in the 1990s. Currently, attempts are being made to revitalize the linen industry in Poland, which is associated with increasing the area of its cultivation.

\section{BIOLOGICAL PROPERTIES AND PERFORMANCE CHARACTERISTICS OF FLAX}

Common flax (Linum usitatissimum L.) belongs to the botanical family of Linaceae, containing over 200 species. The cultivar forms of flax currently used are derived from wild narrow-leaved flax (Linum angustifolium Huds.). 
Narrow-leaved flax developed annual, biennial and perennial forms. The generic name Linum, used by the Greeks and Romans, comes from the Celtic word lin - thread. The second word in the name of this species, i.e. usitatissimum means in Latin - very useful (Rumińska, 1990). The unique and important biological as well as agricultural properties of flax forms (oil and fibrous) have resulted in both being included in crops. In Mesopotamia and Egypt, as well as in Europe, flax was widely used both for the production of textiles and for food purposes in the form of oil (Zając et al., 2010).

Currently, flax is no longer seen only as a source of fabric for clothes or bedding, or cooking oil. Along with the development of civilization and the use of advanced technologies, an increase in the demand for new sources of biodegradable raw production materials is observed, in line with the ecological principles. In recent years, the studies on flax as a potential source of environmentally friendly natural industrial raw materials have been initiated and conducted. Currently, flax provides raw material for the food, textile, chemical, cosmetic, automotive and paper industries (Preisner et al., 2015).

\section{Linen fiber}

The flax fiber comes from the phloem cells and is located on the periphery of the stem, under the epidermis and parenchymal cells. A single cell of flax fiber has an elongated, cylindrical shape, and a thickened cell wall and protoplast disappearing during development. The average length is $27 \mu \mathrm{m}$, the average width of such a cell is $2 \mu \mathrm{m}$. The cross-section of the developing fiber cells shows their polygonal or round shape. The development of fiber cells is divided into three stages: differentiation, elongation and thickening of the cell wall. After cell division and specifications, the fiber cells begin to elongate and differentiate from each other. The growth process is much longer than that of other types of cells in the stem, which allows the fiber cells to reach their remarkable length. During this stage, the protoplast gradually disappears. When the cells have completed their growth, the last stage is the intense thickening of the cell wall with simultaneous continuous disappearance of protoplasts. In this way, the fiber cells reach their state of maturity, with a relatively thick cell wall and small cell lumen. After ripening and harvesting, what remains of the fiber cell is the cell wall - the structure that creates the linseed fiber (Preisner et al., 2015).

After technological processing, fibrous flax is intended for the production of clothing $(60 \%)$, household materials $(15 \%)$, upholstery fabrics $(15 \%)$, and industrial technical fabrics $(10 \%)$. Linen is used in all clothing ranges with particular emphasis on sportswear. The research of the Institute of Natural Fibers and Herb Plants in Poznań regarding the hygienic properties and the comfort of use of clothing and its impact on the human physiological parameters shows that linen is characterized by high hygienic values and the elimination of electrostatic charges. This ensures that it provides an optimal microclimate in the skin-clothing sphere, positively affects the human body, does not cause allergies, strengthens the immune system, and reduces the tendency to fatigue. An important functional feature of linen fabrics is their high hygroscopicity and suitability for the summer clothing collections. The flax fiber contains lignins in its composition, which are an excellent natural absorbent of the UV radiation. Linen fabrics have the bacteriostatic and bactericidal properties. Due to the content of B-type pectins, it becomes softer and more pleasant to the touch as it is used.

The World Health Organization (WHO) defines the antibiotic resistance as one of the major threats to human life. In the EU countries, about 25,000 people die annually due to the infection with the bacteria resistant to antibiotics. The problem is the treatment of difficult-healing wounds and ulcers associated with various diseases, especially at the elderly people. The team of Prof. Jan Szopa prepared a dressing based on flax fiber derived from a genetically modified oilseed Linola, by introducing the genes encoding the key enzymes for flavonoid synthesis (Mańkowski, 2017). The fiber from genetically modified flax is to be used to create a perfect dressing with antibacterial properties (Hameed and Adnan, 2018). The research on obtaining the raw material for the production of qualitatively new dressings was carried out in Poland under the Applied Research Program financed by the National Center for Research and Development entitled "Optimization of new flax productivity and its use as a source of biomedical preparations." 


\section{Linseed and linen oil}

Flax seeds are a source of essential unsaturated fatty acids (NNTK) from the $\omega-3$ group, vitamins $\mathrm{A}$ and $\mathrm{E}$ as well as lignans. According to the American Department of Agriculture (Bartkowski, 2013), flax seeds contain the following amounts of the following substances in $100 \mathrm{~g}$ : carbohydrates $28.8 \mathrm{~g}$, proteins $18.3 \mathrm{~g}$, fats $42.2 \mathrm{~g}$ and many vitamins, while the energy value is 534 kcal. Enzymes and glycosides of oleic, linoleic and stearic acids are also found in the linseed. In the absence of gluten tolerance, it can be replaced by the addition of linseed to a gluten-free bread (Gambuś, 2005).

Linseed (seed) is used in the pharmaceutical industry and traditional folk medicine, due to their proven healing properties.

Complicated and multi-stage production of flax fiber currently does not withstand competition with the industrial and mass technology of cotton and artificial fiber production; therefore, the oilseed flax cultivation prevails. In the world, the area of oilseed flax cultivation has not been significantly reduced for several decades: it is about 2.6 million hectares and is 12 times larger than that of fibrous flax. The global production of flax seeds was 1.93 million tons in 2010 (FAOSTAT, 2020). The oily form of flax is grown in dry, warm or moderate climate countries. The largest producers of flax in the world are: Canada (leader in cultivation and production), China, Russia, India, the United States, Ethiopia, Kazakhstan, Ukraine, Argentina (Hołubowicz-Kliza, 2015). According to Flax Council of Canada (2019), the cultivation and production of flax in this country in 2017 was as follows:

- total cultivation area -423 thousand ha [about 1045 thousand acres]

- linseed production - 555,000 tons

- export of linseed - 468 thousand tons

- linseed oil exports - 2059 tons

- export of linseed meal -3.884 tons

The area of Canadian flax growing accounts for about $50 \%$ of the world's resources.

In Europe, the conditions for flax growing are favorable. Moderate climate and light soils occur on a large area, which favored the cultivation of this plant and caused interest in its cultivation in previous centuries throughout Europe. It was also the reason for the development of the linen industry. The processes of globalization and spread of cotton in the 20th century, as well as the mass production of synthetic fibers, however, initiated a downward trend in flax cultivation. It has only been since 2012 that an upward trend has been observed.

Currently, the area of fiber flax cultivation in the EU amounts to around 80,000 ha, most of which are grown in France, Belgium and the Netherlands. In the coming years, the current acreage of oilseed flax in European Union countries may significantly increase due to new technologies of using raw materials derived from fiber plants and the use of seeds of these plants for the non-nutritional purposes (Kozłowski and Mackiewicz-Talarczyk, 1937; Wielebski, 2012). Poland is the fourth producer of flax raw material in the European Union (Table 2) (HołubowiczKliza, 2015). The gradual rebirth of this crop is shown in Table 2.

Oil flax has been cultivated in Poland for centuries; however, this plant did not constitute a significant area in the crop structure. Oil flax was grown on a larger scale only in the interwar period, mainly in Kujawy (Wałkowski et al., 1998). After the war, oil flax was almost completely abandoned. Recently, the cultivation of oil flax in Poland has been growing rapidly and in 2017 it reached an area of 5875 ha (Table 2). The current structure of obtaining natural oils in Poland is presented in Figure 2.

Decades ago, Poland was considered a leader, and flax was an important export brand. In Białystok - Fasty, there were large textile

Table 2. Cultivation area of flax Linum usitatissimum in Poland in the years 2003-2017 (ha)

\begin{tabular}{|c|c|c|}
\hline \multirow{2}{*}{ Year } & \multicolumn{2}{|c|}{ Form of flax } \\
\cline { 2 - 3 } & Fibrous flax & Oil flax \\
\hline 2003 & 2800 & 740 \\
\hline 2004 & 3456 & 774 \\
\hline 2005 & 5625 & 1016 \\
\hline 2006 & 2586 & 2586 \\
\hline 2007 & 2041 & 1759 \\
\hline 2008 & 2428 & 1341 \\
\hline 2009 & 1897 & 1624 \\
\hline 2010 & 546 & 3441 \\
\hline 2011 & 848 & 2162 \\
\hline 2012 & 640 & 1234 \\
\hline 2013 & 667 & 1470 \\
\hline 2014 & 239 & 2386 \\
\hline 2015 & 295 & 4499 \\
\hline 2016 & 162 & 7457 \\
\hline 2017 & 174 & 5875 \\
\hline
\end{tabular}

[Based on GUS (www.stat.gov.pl)] 


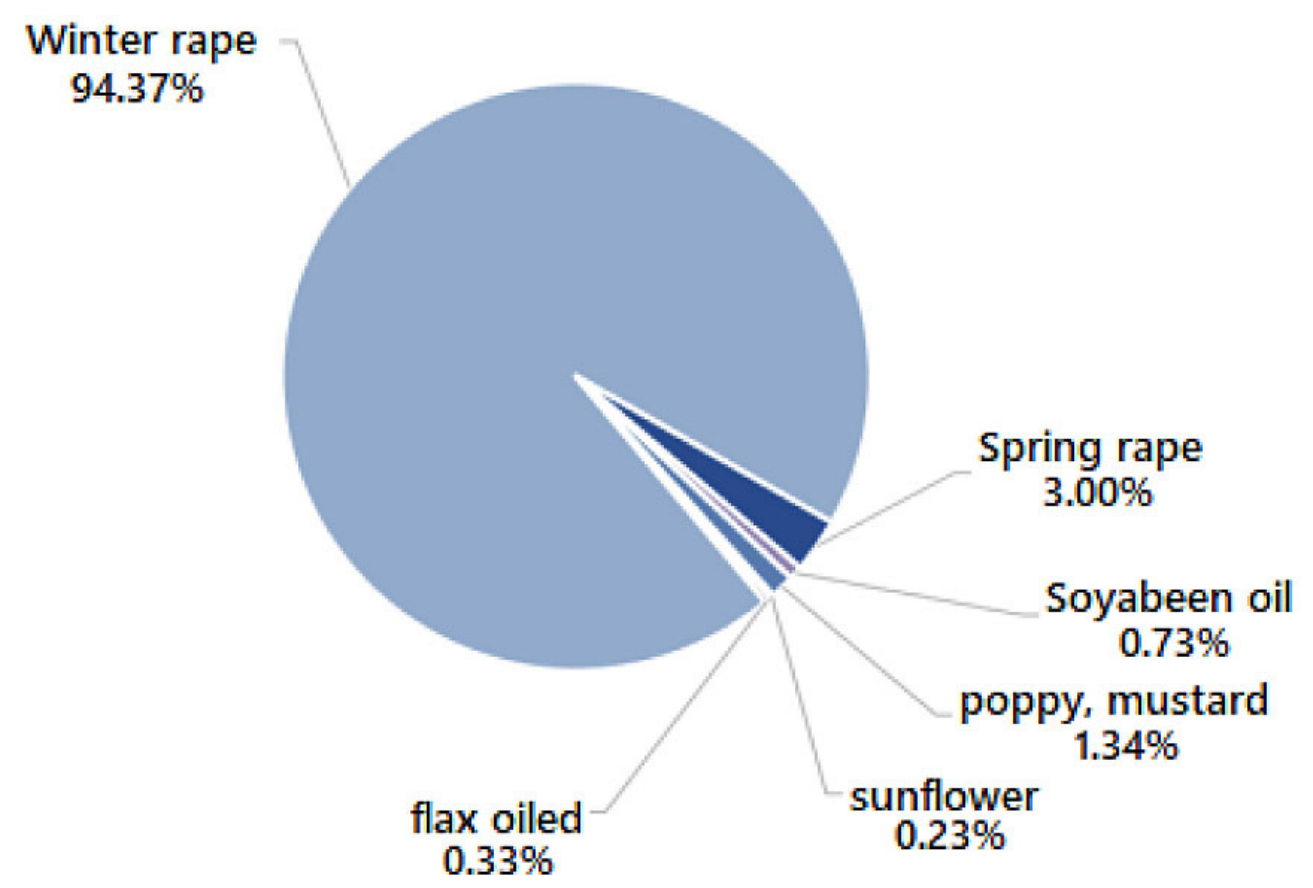

Fig. 2. Sources of obtaining natural oil in Poland today [www.stat.gov.pl]

factories processing most of the flax fiber produced in Poland. These were significant plants in terms of size and produced assortments of linen fabrics. Even in the 1960s, the area of cultivation of this plant averaged 114 thousand hectares. In the 1980s and 1990s, the linen industry collapsed, most factories were shut down, and those that survived had to restructure employment and the production process, as well as maintain their markets, especially in Western Europe and America. In place of the bankrupt state-owned enterprises, new private companies, both Polish and foreign, were created, mainly from France, Belgium and Ireland. The fall in acreage and flax production in Poland continued until 2000 (Silska and Praczyk, 2011). In the period 2000-2004, there was a slight increase in the area of flax cultivation and production. It was only after 2004, after the Poland's accession to the European Union, the acreage of crops and oilseed production began to increase slowly (Table 1). The increase of the area of cultivation and production of linseed in recent years is caused by the possibility of obtaining the EU subsidies and growing interest of consumers in natural foods with healthy properties. Despite the decrease in the acreage of crops, the flax grain yield has increased in the last twenty years from $500 \mathrm{~kg} \cdot \mathrm{ha}^{-1}$ in 1993 to as much as $1,500 \mathrm{~kg} \cdot \mathrm{ha}^{-1}$ in 2016. This is due to the introduction of new varieties and modern cultivation technologies (Popis et al., 2015).

\section{TRADITION OF FLAX FIBER PROCESSING IN POLAND}

The process of obtaining flax fiber is timeconsuming and the obtained fiber quality is the result of many factors. One of the important is the structure of flax fiber and enzymes involved in fiber biosynthesis (Preisner et al., 2015). The amount of fiber and its quality are influenced by the varieties used, climatic conditions, cultivation technology and processing. The traditional processing of flax straw grown in the field includes harvesting (plucking or mowing), drying of straw in the field, de-graining and harvesting of flax seeds, wetting (soaking), brushing and whisking, fiber sorting, combing, spinning. Earlier in the production of flax for the farm's own needs, the individual technological stages were carried out manually and mainly by women. In industrial production in the nineteenth and twentieth century, the greatest technological problems corresponded to the stages of wetting and brushing. They took place in the so-called wetting barns located in places not far from the fields. The pretreated raw material reached the textile factory from cultivation. Currently, due to the disappearance of the flax growing area, the wetting barns have been closed down.

Traditional flax cultivation and processing was very much associated with the life of the Polish village and its traditions. The descriptions of 
these works and rituals are found in many source materials (Poland 1937 magazine). In literature, there is a book by Maria Konopnicka entitled " $A s$ it was with flax" containing the description of the individual stages - from sowing through harvesting, fiber processing to obtaining canvas. The Danish writer Hans Christian Andersen tells the tale of "Flax" about a plant that transforms into yarn, canvas, underwear, paper and manuscript of the book (Bartkowski, 2013).

\section{BASICS OF CULTIVATION PROFITABILITY}

The profitability of the undertaken actions is part of creating a sustainable development order. Comparing the data in the table (Table 3), it is easy to conclude that the flax cultivation can be more profitable than spring barley. To the abovementioned, simplified calculation, it is necessary to add the social usefulness of the measures taken due to the development of the labor market. The health-promoting role of linseed, which is difficult to value in money, should not be overlooked, but it should also strengthen the motivation to increase the area of oils flax cultivation. The technological processing of the obtained flax, especially of flax straw, may be a problem. However, there is the possibility of organizing a new development niche in the socio-economic space of rural areas. Similarly, perhaps when organizing the sale of seeds. As it can be seen, beneficial effects on natural, social and economic space will be achieved as a result of the restitution process of this plant.

\section{RECAPITULATION}

The first decade of the 21st century exposed the weaknesses of modern countries, and the unexpected slowdown in the economy affected the periodic purification of air and other environmental resources. The people who are returning

Table 3. Costs and income from the cultivation of common flax and spring barley in Poland (in PLN)

\begin{tabular}{|l|c|c|}
\hline \multicolumn{1}{|c|}{ Specification } & Common flax & Spring barley \\
\hline $\begin{array}{l}\text { Total cultivation } \\
\text { costs on 1 ha area }\end{array}$ & 4500 & 4300 \\
\hline Income from 1 ha & 7200 & 6000 \\
\hline Revenue & 2700 & 1700 \\
\hline
\end{tabular}

to activity now face a great social and ecological challenge to build better and more strategic relations between the economy and nature in the following decades. New concepts of transformation are urgently needed, developed in cooperation with the local governments, scientists and activists for rural areas, cities, ecology and social welfare (Dearing et al., 2010; Wang et al., 2014).

Humanity cannot afford the expectation of excessive and growing materialistic well-being. We have lived on credit for a long time in relation to the ecosystem services, and this means that we use too much resources. More challenges are coming for a man: drought, forest fires, and floods. Quantifying wealth is deceptive, and borrowing from Earth is dangerous. Wealth ceases to be the condition of a good life. We have to focus on the high quality of public services and the satisfaction of basic social needs, being very careful when approaching those ecological barriers described by many authors (Rockström et al., 2009; Nordhaus et al., 2012) (loss of biodiversity, climate change, use of water resources, loss of the ozone layer, ocean acidification, air pollution, chemical pollution of the planet, surface use, disruption of the nitrogen and phosphorus cycle), which humanity - if it wants to avoid disasters - should not exceed.

One should start with the regeneration of ecosystems and ensure that the consumption of materials and energy takes place within the ecosystem cycles and within their boundaries (Balmford et al., 2011).

Because climate and protection of biodiversity are more important for people's survival than economic growth, we must strive for the chain of goods and services to slow down and minimize the transformation of ecosystems (Kostecka, 2013; Hardt, 2017). The lack of a clear increase in the macroeconomic factors does not preclude a chance for a good life. Currently, increasingly older inhabitants of the Earth may consume less material goods, but they will need more medical care and other services - in the non-material sphere. This can be organized within the new European Green Deal. New and good ideas are needed. One of them may be the The Amsterdam City Donut project/program (Raworth, 2020) reconciling the interests of people and our Planet, taking care of development and prosperity in society, while engaging in the protection of natural ecosystems and Earth's resources. 
Restitution of flax cultivation may prove to be one of the elements of implementing the new perspective in rural areas because:

- flax is an important crop species due to the possibility of obtaining both valuable fiber for the textile industry and healthy linseed oil,

- it is a species with a long cultivation history. It is estimated that it has been cultivated for over five thousand years; the first crops already occurred in the pre-ceramic neolithic,

- flax is not a demanding species, it yields well in moderate climate on medium soils,

- reduction in the area of fiber flax production is due to the lack of flax straw processing and textile processing. This species requires multistage processing technology, which gives a chance to organize many new jobs,

- with a view to improving the health condition of a society, it is expedient to promote linseed oil in nutrition and to use textiles made from a natural raw material, which is flax fiber, to a greater extent. Increasing the area of fiber flax cultivation may result in reduced cotton imports and mitigation of the adverse environmental effects caused by intensive cultivation. It will prove beneficial not only to a human health but also for the environment, which will translate into ecosystem services, with which, in turn, the human well-being is closely related.

\section{Acknowledgements}

The study was conducted as a research project WZ/WBiIŚ/8/2019 in Faculty of Building and Environmental Sciences and financed by Ministry of Science and Higher Education.

\section{REFERENCES}

1. Balmford A., Fisher B., Green R.E., Naidoo R., Strassburg B., Turner R.K., Rodrigues A.S.L. 2011. Bringing ecosystem services into the real world: an operational framework for assessing the economic consequences of losing wild nature. Environ. Resour. Econ. 48. 161-175.

2. Bartkowski L. 2013. Flax seeds - a natural source of health and beauty. Chemik. 673. 186-191.

3. Bible of the Millennium. 2003. Wydawnictwo Pallottinum in Poznań.

4. Biermann F. 2012. Planetary boundaries and earth system governance: exploring the links. Ecol. Econ. 81. 4-9.
5. Buchwald W., Forycka A., Mańkowska G., Silska G. 2017. Protection status of fiber and herbal plants biodiversity in Poland. CDR Brwinów. Zagadnienia Doradztwa Rolniczego. 3. 111-122.

6. Dearing J.A., Braimoh A.K., Reenberg A., Turner B.L., Van der Leeuw S. 2010. Complex land systems: the need for long time perspectives to assess their future. Ecol. Soc. 15. 21(online) URL: http:// www.ecologyandsociety.org/vol15/iss4/art21/

7. FAOSTAT 2020. Food and agriculture data. http:// faostat.fao.org/

8. Flax Council of Kanada. 2019. Flax Focus Fall 2019. https://flaxcouncil.ca/flax-focus-fall-2019/.

9. Gambuś H. 2005. Oil flax seeds (Linum usitatissimum L.) as a source of nutrients in gluten-free bread. Żywność. Nauka. Technologia. Jakość. 4 (45) Supl. 61-74.

10. GUS. 2019. Production of agricultural crops in the years 2002-2017. www. stat.gov.pl

11. Gaweł A. 2009. Agrarian customs, rituals and beliefs in the Bialystok region from the mid-19th to the beginning of the 21 st century. Księgarnia Akademicka. Kraków.

12. Hołubowicz-Kliza G. 2015. Integrated production of oil flax. IUNG-PIB Puławy.

13. Hameed I., Adnan I. 2018. Linum usitatissimum: Anti-bacterial Activity, Chromatography, Bioactive Compounds, Applications: A Review. International Journal of Pharmaceutical Quality Assurance. 9. 170-173.

14. Hardt J.N. 2017. Environmental Security in the Anthropocene: Assessing Theory and Practice. Routledge Publisher. DOI: 10.4324/9781315202471

15. Hunter B. 2012. European Flax - new label guarantees quality. https://www.knittingindustry.com/ european-flax-new-label-guarantees-quality/

16. Kaeufler G. 1999. Cultivation methods to make flax profitable. Top Agrar Special 2. 20-21.

17. Kostecka J. 2013. Self evaluation on the way to retardation of pace of life and resources transformation. Problems of Sustainable Development. 8. (2). 93-102.

18. Kostecka J. 2019. Ecological Engineering - a View on Tasks and Challenges. Journal of Ecological Engineering. DOI:10.12911/22998993/112552.

19. Kostecka J., Butt K.R. 2019. Violence on the Natural Environment. Problemy ekorozwoju - problems of sustainable development. vol. 14. no 2. 183-189.

20. Kozłowski R.M., Mackiewicz-Talarczyk M. 2000. Handbook of Natural Fibres: Volume 1. Types, Properties and Factors. Elsevier. 93-156.

21. Lewandowski A. 2008. New times for flax. http:// www.farmer.pl/produkcja-roslinna/inne-uprawy/ wlokniste/nowe-czasy-dla-lnu,7369.html. 
22. Lityńska-Zając M., Wasylikowa K. 2005. Common flax - Linum usitatissimum L. [in:] Guide to archaeobotanical research. Sorus Poznań. 127-129.

23. Łuczaj Ł. 2011. Herbal bouquets blessed on Assumption Day in south-eastern Poland: freelisting versus photographic inventory. Ethnobotany Research and Applications. 9. 1-25.

24. Mańkowski J. 2017. Development and yielding of fibrous flax. [in:] A. Kotecki, Genetically modified fibrous flax (Linum usitatissimum L.) - Reaction to various seeding rates and selection of genotypes. UP Wrocław. http://wydawnictwo.up.wroc.pl/.

25. Millenium Ecosystem Assessment. 2005. Ecosystems and Human Well-being. Island Press. Washington. DC.

26. Musiał K. 2017. Medicinal plants in the earliest documents of medical knowledge. Rozprawy Społeczne. 11(4). 56-63. https://doi.org/10.29316/ rs.2017.39.

27. Nordhaus T., Shellenberger M., Blomqvist L. 2012. The Planetary Boundaries Hypothesis. A Review of the Evidence. Breakthrough Institute. Oakland. CA.

28. Nowiński M. 1970. History of crops and arable crops. PWRiL Warszawa.

29. Kozłowski R.M., Mackiewicz-Talarczyk M. 1937. Polska. Polish flax. Czasopismo. Wyd. Światowy Związek Polaków za Zagranicą. 8. https://docplayer.pl/49065804.

30. Popis E., Ratusz K., Przybysz M., Krygiel K., Sakowska A., Konarska M. 2015. World and Polish production of oil flax and linseed oil. Zesz. Problemowe Szkoły Głównej Gospodarstwa Wiejskiego w Warszawie. Problemy Rolnictwa Światowego. 15. 106-116.

31. Preisner M., Wojtasik W., Szopa J. Kulma A. 2015. Development, differentiation and composition of flax fiber cells. Postępy Biochemii. 61. (4). https:// postepybiochemii.ptbioch.edu.pl.

32. Raworth K. 2020. The Amsterdam City Doughnut. A tool for transformative action. https://www.kateraworth.com/2020/04/08/amsterdam-city-doughnut/.

33. Rockström J., Steffen W., Noone K., Person A., Chapin S.F., Lamin E.F., Lenton T.M., Scheffer M., Folke C., Schellnhuber H.J., Nykvist B., de Wit C.A., Hughes T., van der Leeuw S., Rodhe H., Sörlin S., Synder P.K., Costanza R., Svedin U., Falkenmark M., Karlberg L., Corelli R.W., Fabry V.J., Hansen J., Walker B., Liverman D., Richardson K., Crutzen P., Foley J.A. 2009. A safe operating space for humanity. Nature. 461. 472-475.

34. Rumińska A. 1990. Common flax. Lexicon of medicinal plants. PWRiL Warszawa.

35. Silska G., Praczyk M. 2011. Flax seeds and linseed oil are a valuable source of omega-3 fatty acids. Biuletyn Informacyjny Polskiej Izby Lnu i Konopi. Len i Konopie. 17. 50-56.

36. Wałkowski T., Ladek A., Piotrowska A. 1998. Oil flax. IHAR Poznań.

37. Wang R., Zhang K., Dyke J.D., Haberl H., Hossain Md. S., Langdon P.G., Lenton T.M., Raworth K., Brown S., Carstensen J., Cole M.J., Cornell S.E., Dawson T.P., Doncaster C.P., Eigenbrod F., Flörke M., Jeffers E., Poppy G.M. 2014. Safe and just operating spaces for regional social-ecological systems. Global Environmental Change. Vol. 28. 227-238. doi.org/10.1016/j.gloenvcha.2014.06.012.

38. Wielebski F. 2012. Contents of harmful substances in seeds and straw of oil flax (Linum usitatissimum L.) cultivated in the immediate vicinity of communication routes. Oilseed crops. Rośliny oleiste. t. 23. $113-126$.

39. Wilson E.O. 2016. Half-Earth: Our Planet's Fight for Live. Liveright Publishing Corporation. New York- London.

40. Zając T., Oleksy A., Kulig B., Klimek A. 2010. Conditions for yielding the oil form of flax (Linum usitatissimum L.) and its nutritional and therapeutic significance. Acta Sci. Pol. Agricultura. 9(2). 47-63. 